\title{
Fatty Acid Contents of Brazilian Soybean Oils with Emphasis on trans Fatty Acids
}

\author{
Clayton Antunes Martin, Jesuí Vergílio Visentainer, Adriana Nery de Oliveira, \\ Claudio Celestino de Oliveira, Makoto Matsushita and Nilson Evelázio de Souza*
}

Departamento de Química, Universidade Estadual de Maringá, Av. Colombo, 5790, 87020-900 Maringá-PR, Brazil

\begin{abstract}
As composições em ácidos graxos das principais marcas de óleo de soja consumidas pelos brasileiros foram determinadas. Em média os níveis de ácidos graxos trans (TFA) variaram entre 0,8 e 2,6\% do total de ácidos graxos e compreendem os isômeros 18:1, 18:2, e 18:3. Os níveis de TFA 18:1 foram menores que $0,1 \%$ em todas as marcas estudadas. Entre os TFA poliinsaturados, 18:3 foi o predominante, com níveis variando de 0,5 a 1,4\%. Este grupo compreende ácidos graxos mono e di-trans e o principal foi o 18:3 9c, 12c, 15t. As quantidades de TFA 18:2 variaram de 0,3 a $1,1 \%$ com predominância do ácido $18: 29 c, 12 t$. Teores do ácido alfa-linolênico variaram de 3,5 a $5,4 \%$, com um valor médio de $4,1 \%$. O grau de isomerização dos ácidos linoléico e alfa-linolênico variaram de 0,5 a $2,1 \%$ e de 9,1 a $27,2 \%$, respectivamente. Este estudo indica que provavelmente o tratamento térmico aplicado durante o passo de desodorização dos óleos nos últimos anos foi intenso, resultando em uma diminuição significativa do teor de ácido alfa-linolênico no óleo e, em um aumento na razão n-6/n-3 da dieta dos brasileiros.
\end{abstract}

The fatty acid composition of the main soybean oil brands consumed by the Brazilian has been determined. The mean trans fatty acids (TFA) levels ranged between 0.8 and $2.6 \%$ of the total fatty acids and comprised 18:1, 18:2, and 18:3 isomers. 18:1 TFA levels were lower than $0.1 \%$ in all the studied brands. Among the polyunsaturated TFA, 18:3 predominated, with levels ranging from 0.5 to $1.4 \%$. This group comprised mono and di-trans fatty acids and the main acid was $18: 39 c, 12 c, 15 t$. The amounts of 18:2 TFA ranged from 0.3 to $1.1 \%$ with a predominance of acid 18:2 $9 c, 12 t$. Alpha-linolenic acid contents ranged from 3.5 to $5.4 \%$, with a mean value of $4.1 \%$. The degree of isomerization of linoleic and alpha-linolenic acids ranged from 0.5 to $2.1 \%$ and from 9.1 to $27.2 \%$, respectively. This study probably indicates that the thermal treatment applied to soybean oil during the deodorization step in the last years is too intense and that it results in a significant decrease in oil alpha-linolenic acid content and an increase in the $n-6 / n-3$ ratio in the Brazilian diet.

Keywords: trans fatty acids, soybean oils, degree of isomerization

\section{Introduction}

In the last decades, soybean has been the most consumed oil in many countries. Brazil has contributed to this consumption in a great deal, as it is responsible for $22 \%$ of the world soybean production, which makes it the second largest soybean oil producer and exporter. ${ }^{1}$ Due to the fact that its alpha-linolenic $(18: 39 c, 12 c, 15 c)$ level usually ranges from 5.0 to $7.0 \%$ of the total fatty acids, ${ }^{2,3}$ soybean oil is an important daily source of this acid. It also has a

*e-mail: nesouza@uem.br significant effect on the n-6/n-3 fatty acids ratio of the diet of many people.

Refining of soybean oil includes degumming, neutralization, bleaching, and deodorization steps. Isomerization reactions carried out during the deodorization step may reduce alpha-linolenic acid levels significantly. A raise in temperature increases the rate of these reactions. ${ }^{4}$ Consequently, the oil trans fatty acid (TFA) levels increase.

TFA are fatty acids containing at least one trans double bond. In trans form hydrogen atoms are located on either side of the carbon atoms, whereas those in the cis form are located on the same. trans Isomers class include monounsaturated trans fatty acids (TMFA), a group of fatty acids 
that have only one unsaturation, which is necessarily in the trans form. Trans polyunsaturated fatty acids (TPFA) also belong to this class of isomers, and similarly to their cis counterparts, have two or more unsaturations, either all trans or not.

While TMFA are generally produced by hydrogenation of vegetable oils (Figure 1) or biohydrogenation in rumminants, TPFA are formed as a result of deodorization of oils ${ }^{4}$ or frying treatments. ${ }^{5}$ Intake of foods containing high TMFA amounts has been associated with the risk of development of cardiovascular disease, ${ }^{3,6,7}$ due to the hazardous effects of these fatty acids on plasma lipoproteins that increase low density lipoprotein (LDL-c) and lipoprotein [a] levels and decrease the levels of high density lipoprotein (HDL-c).

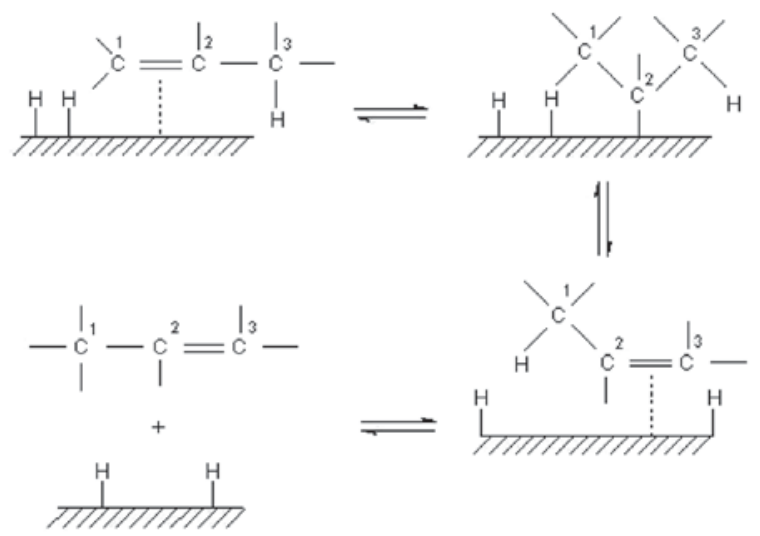

Figure 1. trans Fatty acid formation in the hidrogenation process.

Although it has been observed that the daily intake of $1.4 \mathrm{~g}$ of TPFA 18:3 does not cause significant changes in the LDL-c and HDL-c plasma levels, a significant increase in the LDL-c/HDL-c ratio has been associated to the consumption of these isomers. ${ }^{8}$ This ratio is one of the main indicators of cardiovascular disease risk and thus a high TPFA intake may contribute to its increase.

The object of this study is to investigate the fatty acid composition of the soybean oil brands most consumed by the Brazilian population in the last two years with emphasis on TPFA, and alpha-linolenic acid.

\section{Experimental}

\section{Sampling}

Five soybean oil brands of major Brazilian oil processing companies were analyzed. The brands were labeled A, B, C, D, and E and were evaluated in six brand lots between September 2003 and October 2005. Each lot was analyzed separately and in triplicate.
Analysis

The preparation of fatty acid methyl esters (FAME) was carried out according to the methods proposed by Hartman and Lago. ${ }^{9}$ The amount of $30 \pm 1 \mathrm{mg}$ of soybean oil was weighed in a test tube and the lipids were saponified in $0.5 \mathrm{~mol} \mathrm{~L}^{-1}$ sodium hydroxide in methanol and esterified with a mixture of ammonium chloride, methanol, and sulfuric acid at 1:30:1.5 (m/v/v). After the addition of the saturated sodium chloride solution, the FAME was extracted with $1 \mathrm{~mL}$-heptane. FAME were separated in a gas chromatographer 14-A (Shimadzu, Japan) equipped with a fused silica capillary column CP Sil-88 $(50 \mathrm{~m} \times 0.25 \mathrm{~mm}$ i.d., $\times 0.25 \mu \mathrm{m}$ biscyanopropyl polysiloxane) and a flame ionization detector. The gas flow rates used were $1.2 \mathrm{~mL}$ min $^{-1}$ carrier gas $\left(\mathrm{H}_{2}\right), 30 \mathrm{~mL} \mathrm{~min}^{-1}$ make-up gas $\left(\mathrm{N}_{2}\right)$, and 30 and $300 \mathrm{~mL} \mathrm{~min}^{-1}$ flame gases $\left(\mathrm{H}_{2}\right.$ and synthetic air, respectively). Sample splitting rate was 1:50. The column was heated to $170{ }^{\circ} \mathrm{C}$ in 14 minutes and then the temperature was raised to 225 at $15^{\circ} \mathrm{C} \mathrm{min}{ }^{-1}$. Injector and detector temperatures were $225^{\circ} \mathrm{C}$ and $245^{\circ} \mathrm{C} \mathrm{min}{ }^{-1}$, respectively. Samples $(2 \mu \mathrm{L})$ were injected. Peak areas were determined by an Integrator-Processor CG-300 (Instrumentos Científi$\cos \mathrm{CG})$. The results are expressed as relative area percentages. TPFA 18:2 and 18:3 were identified with FAME of isomerized linseed oil prepared according to Grangirard et al. ${ }^{10}$ Elution order of the 18:2 and 18:3 trans isomers in this reference mixture was based on equivalent chain length (ECL) values determined by Wolff ${ }^{11}$ for CP Sil-88 column. FAME mixture standard 189-19 (Sigma) and vaccenic acid methyl ester standard (Sigma) were used for identification of others fatty acids contained in oil. ECL values were determined for all analyzed acids using a method described by Ackman ${ }^{12}$ with methyl esters of 16:0, 18:0, and 20:0 as reference compounds.

\section{Degree of isomerization}

The degree of isomerization (DI) of linoleic (18:2 $9 c, 12 c)$ and alpha-linolenic acid $(18: 39 c, 12 c, 15 c)$ were determined by the ratio between the trans forms and total cis and trans forms:

$$
\text { ID }(\%)=\frac{\text { trans }-18: \mathrm{x}}{\text { cis }-18: \mathrm{x}+\text { trans }-18: \mathrm{x}} \times 100
$$

\section{Statistics}

The means were compared by variance analysis (ANOVA) with 5\% significance level with Tukey's test. The significance of the relations between fatty acids was examined by correlation analysis. $P$ value $\leq 0.05$ was considered significant and 
are represented by different letters for results presented in the same line in Tables 1 and 2. All statistical analyses were performed with Statistica 5.0 software. ${ }^{13}$

\section{Results and Discussion}

Table 1 contains the fatty acid composition of the studied soybean oil brands. The predominant saturated fatty acids were palmitic (16:0) and stearic. Arachidic (20:0) and behenic (22:0) acids were also detected. The detected levels of palmitic acid were between 11.31 and $11.77 \%$ and no significant difference ( $\mathrm{P}>0.05)$ were observed among the samples as evidenced by the Tukey's test ( $a$ letter for all values of Table 1, line 2). Stearic acid levels ranged from 3.23 to $3.83 \%$ and the value

Table 1. Fatty acid composition of Brazilian soybean oil brands ${ }^{1}$

\begin{tabular}{|c|c|c|c|c|c|}
\hline \multirow{2}{*}{ Fatty acids } & \multicolumn{5}{|c|}{ Brands } \\
\hline & A & B & $\mathrm{C}$ & $\mathrm{D}$ & $\mathrm{E}$ \\
\hline $16: 0$ & $11.77 \pm 0.96^{\mathrm{a}}$ & $11.29 \pm 0.91^{\mathrm{a}}$ & $11.46 \pm 0.78^{\mathrm{a}}$ & $11.31 \pm 0.50^{\mathrm{a}}$ & $11.62 \pm 0.76^{a}$ \\
\hline 18:0 & $3.23 \pm 0.37^{\mathrm{a}}$ & $3.77 \pm 0.46^{\mathrm{b}}$ & $3.83 \pm 0.44^{b}$ & $3.60 \pm 0.37^{\mathrm{ab}}$ & $3.76 \pm 0.79^{b}$ \\
\hline $18: 1 t^{2}$ & $0.07 \pm 0.02^{\mathrm{a}}$ & $0.04 \pm 0.03^{\mathrm{b}}$ & $0.05 \pm 0.01^{\mathrm{b}}$ & $0.03 \pm 0.01^{\mathrm{b}}$ & $0.04 \pm 0.02^{\mathrm{b}}$ \\
\hline $18: 19 c$ & $22.27 \pm 2.28^{\mathrm{a}}$ & $23.43 \pm 1.00^{\mathrm{ab}}$ & $24.75 \pm 2.50^{\mathrm{b}}$ & $22.32 \pm 1.64^{\mathrm{a}}$ & $22.75 \pm 1.34^{\mathrm{a}}$ \\
\hline $18: 111 c$ & $1.54 \pm 0.36^{\mathrm{a}}$ & $1.42 \pm 0.25^{\mathrm{a}}$ & $1.48 \pm 0.48^{\mathrm{a}}$ & $1.50 \pm 0.31^{\mathrm{a}}$ & $2.23 \pm 0.74^{\mathrm{b}}$ \\
\hline $18: 29 c, 12 t$ & $0.66 \pm 0.24^{\mathrm{a}}$ & $0.26 \pm 0.11^{\mathrm{bc}}$ & $0.37 \pm 0.20^{c}$ & $0.15 \pm 0.08^{b}$ & $0.32 \pm 0.26^{\mathrm{bc}}$ \\
\hline $18: 29 t, 12 c$ & $0.56 \pm 0.21^{\mathrm{a}}$ & $0.22 \pm 0.10^{\mathrm{bc}}$ & $0.30 \pm 0.16^{\mathrm{c}}$ & $0.12 \pm 0.08^{b}$ & $0.30 \pm 0.22^{\mathrm{bc}}$ \\
\hline $18: 29 c, 12 c$ & $53.52 \pm 1.75^{\mathrm{ac}}$ & $52.51 \pm 0.72^{\mathrm{abc}}$ & $51.29 \pm 1.95^{\mathrm{b}}$ & $53.80 \pm 1.06^{\mathrm{c}}$ & $52.39 \pm 1.56^{\mathrm{ab}}$ \\
\hline $20: 0$ & $0.26 \pm 0.06^{\mathrm{a}}$ & $0.38 \pm 0.09^{\mathrm{b}}$ & $0.35 \pm 0.09^{\mathrm{bc}}$ & $0.27 \pm 0.06^{\mathrm{a}}$ & $0.28 \pm 0.08^{\mathrm{a}}$ \\
\hline $18: 39 t, 12 c, 15 t$ & $0.12 \pm 0.08^{\mathrm{a}}$ & $0.03 \pm 0.02^{\mathrm{b}}$ & $0.08 \pm 0.06^{\mathrm{ab}}$ & $\mathrm{ND}$ & $0.07 \pm 0.05^{\mathrm{b}}$ \\
\hline $18: 39 c, 12 c, 15 t$ & $0.67 \pm 0.21^{\mathrm{a}}$ & $0.33 \pm 0.12^{\mathrm{bc}}$ & $0.45 \pm 0.11^{\mathrm{b}}$ & $0.26 \pm 0.10^{c}$ & $0.42 \pm 0.19^{b}$ \\
\hline $18: 39 t, 12 c, 15 c^{3}$ & $0.69 \pm 0.21^{\mathrm{a}}$ & $0.32 \pm 0.11^{\mathrm{bc}}$ & $0.41 \pm 0.13^{\mathrm{b}}$ & $0.25 \pm 0.11^{\mathrm{c}}$ & $0.40 \pm 0.22^{\mathrm{b}}$ \\
\hline $18: 3 n-3$ & $3.47 \pm 0.50^{\mathrm{a}}$ & $4.73 \pm 0.91^{\mathrm{c}}$ & $4.09 \pm 0.51^{\mathrm{ac}}$ & $5.42 \pm 0.68^{b}$ & $4.39 \pm 0.79^{c}$ \\
\hline $20: \ln -9$ & $0.20 \pm 0.04^{\mathrm{a}}$ & $0.21 \pm 0.05^{\mathrm{ab}}$ & $0.26 \pm 0.07^{\mathrm{b}}$ & $0.19 \pm 0.07^{\mathrm{a}}$ & $0.22 \pm 0.09^{\mathrm{ab}}$ \\
\hline $22: 0$ & $0.40 \pm 0.07^{\mathrm{a}}$ & $0.50 \pm 0.06^{\mathrm{b}}$ & $0.45 \pm 0.09^{\mathrm{ab}}$ & $0.43 \pm 0.05^{\mathrm{a}}$ & $0.46 \pm 0.07^{\mathrm{a}}$ \\
\hline
\end{tabular}

${ }^{1}$ The values are means \pm S.D. of 6 cans analyzed in triplicate. Results expressed as percentage of total fatty acid methyl esters. Means followed by different letters on the same line are significantly different $(\mathrm{P}<0.05)$ in Tukey's test. ND $=$ not detected. Other fatty acids with levels lower than $0.1 \%$ include $14: 0$, 16:1, 20:2, 22:1, 24:0, and unidentified fatty acids. ${ }^{2}$ Comprises isomers 18:1 $9 t$ and 18:1 $11 t .{ }^{3}$ Comprises isomers $18: 39 c, 12 t, 15 c$.

Table 2. Total fatty acids, degree of isomerization, and n-6/n-3 ratio of the studied soybean oil brands

\begin{tabular}{|c|c|c|c|c|c|}
\hline & \multicolumn{5}{|c|}{ Brands } \\
\hline & A & B & $\mathrm{C}$ & $\mathrm{D}$ & $\mathrm{E}$ \\
\hline $18: 2 t$ & $1.13 \pm 0.41^{\mathrm{a}}$ & $0.48 \pm 0.21^{\mathrm{bc}}$ & $0.67 \pm 0.36^{\mathrm{b}}$ & $0.28 \pm 0.16^{\mathrm{c}}$ & $0.59 \pm 0.47^{\mathrm{bc}}$ \\
\hline $18: 3 t$ & $1.38 \pm 0.48^{\mathrm{a}}$ & $0.68 \pm 0.26^{\mathrm{bc}}$ & $0.93 \pm 0.29^{\mathrm{b}}$ & $0.52 \pm 0.22^{\mathrm{c}}$ & $0.88 \pm 0.46^{\mathrm{b}}$ \\
\hline $18: 3^{1}$ & $4.96 \pm 0.20^{\mathrm{a}}$ & $5.41 \pm 0.68^{b}$ & $5.02 \pm 0.39^{\mathrm{ab}}$ & $5.93 \pm 0.49^{c}$ & $5.27 \pm 0.41^{\mathrm{ab}}$ \\
\hline SFA & $15.67 \pm 0.64^{\mathrm{ab}}$ & $15.94 \pm 0.49^{\mathrm{ab}}$ & $16.09 \pm 0.53^{\mathrm{a}}$ & $15.61 \pm 0.43^{b}$ & $16.10 \pm 0.27^{\mathrm{a}}$ \\
\hline MUFA & $24.01 \pm 1.96^{\mathrm{a}}$ & $25.06 \pm 0.85^{\mathrm{ab}}$ & $26.50 \pm 2.34^{\mathrm{b}}$ & $24.00 \pm 1.63^{\mathrm{a}}$ & $25.20 \pm 1.44^{\mathrm{ab}}$ \\
\hline PUFA & $56.99 \pm 1.87^{\mathrm{a}}$ & $57.24 \pm 1.06^{\mathrm{a}}$ & $55.38 \pm 2.05^{\mathrm{b}}$ & $59.23 \pm 1.65^{\mathrm{c}}$ & $56.78 \pm 1.16^{\mathrm{ab}}$ \\
\hline TPFA & $2.51 \pm 0.87^{\mathrm{a}}$ & $1.16 \pm 0.46^{\mathrm{bc}}$ & $1.60 \pm 0.64^{b}$ & $0.80 \pm 0.37^{\mathrm{c}}$ & $1.47 \pm 0.93^{\mathrm{b}}$ \\
\hline TFA & $2.58 \pm 0.88^{a}$ & $1.20 \pm 0.47^{\mathrm{bc}}$ & $1.64 \pm 0.64^{\mathrm{b}}$ & $0.83 \pm 0.37^{\mathrm{c}}$ & $1.51 \pm 0.94^{\mathrm{b}}$ \\
\hline DI 18:2(\%) & $2.08 \pm 0.75^{\mathrm{a}}$ & $0.90 \pm 0.37^{b c}$ & $1.27 \pm 0.64^{\mathrm{b}}$ & $0.53 \pm 0.30^{c}$ & $1.10 \pm 0.86^{\mathrm{b}}$ \\
\hline DI 18:3(\%) & $27.18 \pm 9.35^{\mathrm{a}}$ & $13.17 \pm 6.26^{\mathrm{bc}}$ & $18.65 \pm 6.25^{\mathrm{b}}$ & $9.06 \pm 4.46^{c}$ & $17.18 \pm 9.97^{\mathrm{b}}$ \\
\hline$n-6 / n-3^{2}$ & $14.76 \pm 1.90^{\mathrm{a}}$ & $11.50 \pm 2.26^{\mathrm{bc}}$ & $12.73 \pm 1.71^{\mathrm{b}}$ & $10.10 \pm 1.20^{c}$ & $12.38 \pm 2.74^{\mathrm{b}}$ \\
\hline$n-6 / n-3^{3}$ & $10.83 \pm 0.59^{a}$ & $9.95 \pm 1.29^{\mathrm{bc}}$ & $10.40 \pm 0.75^{\mathrm{ac}}$ & $9.19 \pm 0.70^{b}$ & $10.13 \pm 1.13^{\mathrm{ac}}$ \\
\hline
\end{tabular}

Means followed by different letters on the same line are significantly different $(\mathrm{P}<0.05)$ in Tukey's test. SFA: saturated fatty acids; MUFA: monounsaturated fatty acids; PUFA: polyunsaturated fatty acids; TPFA: trans polyunsaturated fatty acids; TFA: trans fatty acids; DI: degree of isomerization; ${ }^{1}$ comprises trans and cis isomers; ${ }^{2}$ only cis fatty acids considered; ${ }^{3}$ comprises all isomers. 
obtained for brand A was significantly lower $(\mathrm{P}>0.05)$ than those of brands B, C, and E.

Monounsaturated cis fatty acids comprised oleic (18:19c), cis-vaccenic (18:1 11c), and gondoic (20:1 11c) acids. Oleic acid levels ranged from 22.27 to $24.75 \%$ and the value obtained for brand $\mathrm{C}$ was significantly higher $(\mathrm{P}<0.05)$ than those obtained for brands A, D, and E. These values were close to the ones obtained by Wolff, ${ }^{3}$ who detected oleic acid levels ranging from 18.9 to $23.9 \%$ when he analyzed English and Belgian soybean oil brands. The levels of cis-vaccenic acid ranged from 1.42 to $2.23 \%$. Brand E exhibited a significantly higher value $(\mathrm{P}<0.05)$ than the other brands did.

As for the polyunsaturated fatty acids, linolenic acid $(18: 29 c, 12 c)$ levels ranged between 51.29 and $53.80 \%$, with a significantly lower value $(\mathrm{P}<0.05)$ observed for brand $\mathrm{C}$ in comparison with brands $\mathrm{A}$ and $\mathrm{D}$. Values between 3.47 and $5.42 \%$ were obtained for alpha-linolenic acid $(18: 39 c, 12 c, 15 c)$ levels, with a significantly higher value $(\mathrm{P}<0.05)$ for brand $\mathrm{D}$. Alpha-linolenic acid levels presented a wide variation, which was not observed for the other fatty acids determined. This can be attributed to the variability associated to the intensity of the thermal treatment employed in the oil deodorization step. Temperatures higher than $220^{\circ} \mathrm{C}$ contribute strongly to the isomerization of alpha-linolenic acid. ${ }^{7}$

Monounsaturated and polyunsaturated TFA were found in all the studied brands. The TFA 18:1 levels obtained were very low, with values lower than $0.1 \%$. The levels verified for linoleic acid geometric isomers ranged from 0.15 to $0.66 \%(18: 29 \mathrm{c}, 12 t)$ and from 0.12 to $0.56 \%(18: 29 t, 12 c)$. 18:3 TFAs comprised mainly mono-trans isomers, with levels ranging between 1.4 and $0.5 \%$. Between 92 and $100 \%$ of all the TFA were mono-trans isomers. 18:3 9t,12c,15t acid was detected in almost all the brands, except for brand E, whose levels ranged from 0.03 to $0.12 \%$.

Table 2 gives the total fatty acids and the degree of isomerization of the linoleic and alpha-linolenic acids. The total TFA found in the soybean oil ranged between 0.83 and $2.58 \%$, with 18:2 and 18:3 TFA levels ranging between 0.28 and $1.13 \%$ and 0.52 and $1.38 \%$, respectively. A significantly higher value $(\mathrm{P}<0.05)$ was obtained for brand A. Although the levels of linoleic acid found in soybean oil are much higher than those of alpha-linolenic acid, higher concentrations of 18:3 TFA were observed in all studied brands. This occurs because the bonds of alpha-linolenic acid are more labile than those of linoleic acid, which results in a 25-fold larger isomerization selectivity for $18: 39 c, 12 c, 15 c$ acids if deodoration is performed at $200{ }^{\circ} \mathrm{C}$, or 12 -fold larger if performed at $260^{\circ} \mathrm{C}$, as determined by Hénon et al. ${ }^{4}$

The total level of alpha-linolenic acid and its geometric isomers ranged from 4.96 to $5.96 \%$ (Table 2). These levels are lower than those observed by Karabulat et al., ${ }^{14}$ who obtained $6.8 \%$ when studying soybean oil produced in Turkey. Wolff ${ }^{3}$ obtained 18:3 levels ranging between 6.4 and 8.3 for Belgian soybean brands, $7.5 \%$ for German brands, and $7.2 \%$ for English brands. As for soybean oil produced in the USA, levels between 6.0 and 7.6 were found by Enig et al. ${ }^{2}$ Comparison of these results with the ones of this study indicates that Brazilian soy contains less alpha-linolenic acid. This might be the result of seasonal differences and of the development of new species. It have been observed in studies with other oilseeds, such as canola and linseed, that climatic factors have an effect on linolenic-acid levels. ${ }^{15}$

The $18: 29 c, 12 c / 18: 39 c, 12 c, 15 c(\mathrm{n}-6 / \mathrm{n}-3)$ ratio ranged between 10.10 and 14.76. A significantly lower value $(\mathrm{P}<0.05)$ was obtained for brand $\mathrm{D}$ in comparison with $\mathrm{A}, \mathrm{C}$, and $\mathrm{E}$. When the trans isomers were added to the total n- 6 and n-3 fatty acids the n- $6 / n-3$ ratio ranged from 9.1 to 10.8 . These values correspond to the $n-6 / n-3$ ratio of soybean oil previous to deodoration, since degumming, bleaching, and neutralization do not have a significant effect on TFA formation ${ }^{16}$ as the temperature in these steps does not usually exceed $120^{\circ} \mathrm{C}$.

The degree of isomerization of linoleic and alphalinolenic acids ranged from 0.53 to $2.08 \%$ and from 9.06 to $27.18 \%$, respectively. These results were similar to those obtained by Wolff ${ }^{11}$ for oil brands available in France. His studies led to values ranging between 0.2 and 2.0, and 2.3 and 27.2 for the degrees of isomerization of linoleic and alpha-linolenic acids, respectively. The results obtained in a study carried out by Wolff ${ }^{3}$ with soybean oil from Belgium, Germany, and England indicated that the degree of isomerization ranged from 1.2 to 1.7 for linoleic acid and from 6.3 to $22.6 \%$ for alpha-linolenic acid. As alphalinolenic acid is more labile than linoleic acid, its degree of isomerization is an important indicator of the intensity of the thermal treatment applied to soybean oil in the deodoration step.

Table 3 shows the correlation coefficients between the main fatty acids found in soybean oil. A strong negative correlation was observed between the total 18:2 (trans + cis forms) and oleic acid $(\mathrm{r}=-0.91)$. A strong inverse correlation was observed between the total 18:2 and stearic acid $(\mathrm{r}=-0.82)$; however, it was less pronounced. There was no correlation between the total 18:2 and 18:3 acids. This result indicates that a decrease in the level of alpha-linolenic acid in soybean is not associated with the increase in the level of linoleic acid, resulting in a lesser variability of the $n-6 / n-3$ ratio. The levels of $18: 2 t$ and $18: 3 t$ acids exhibited a strong positive correlation $(\mathrm{r}=$ $0.98)$ as well as the DI 18:2 and 18:3 ( $r=0.97)$, show- 
Table 3. Correlations between the main fatty acids contained in soybean oil

\begin{tabular}{|c|c|c|c|c|c|}
\hline correlations & $\mathrm{r}$ & $\mathrm{p}$ & correlations & $\mathrm{r}$ & $\mathrm{p}$ \\
\hline $18: 0 ; 16: 0$ & -0.78 & 0.0000 & $18: 2 ; 18: 1 \mathrm{n}-9$ & -0.91 & 0.0000 \\
\hline $18: 1 \mathrm{n}-9 ; 16: 0$ & -0.63 & 0.0002 & $18: 3 ; 18: 1 \mathrm{n}-9$ & -0.14 & 0.4486 \\
\hline $18: 2 ; 16: 0$ & 0.57 & 0.0010 & $18: 2 ; 18: 3$ & 0.03 & 0.8769 \\
\hline $18: 3 ; 16: 0$ & -0.50 & 0.0049 & $18: 2 t ; 18: 3 t$ & 0.98 & 0.0000 \\
\hline $18: 1 \mathrm{n}-9 ; 18: 0$ & 0.70 & 0.0000 & $18: 2 \mathrm{n}-6 ; 18: 2 t$ & 0.17 & 0.3626 \\
\hline $18: 2 ; 18: 0$ & -0.82 & 0.0000 & $18: 3 \mathrm{n}-3 ; 18: 3 t$ & -0.86 & 0.0000 \\
\hline $18: 3 ; 18: 0$ & 0.32 & 0.0863 & ID $18: 2 ;$ ID $18: 3$ & 0.97 & 0.0000 \\
\hline
\end{tabular}

ing that the isomerization of linoleic and alpha-linoleic acids is favored by the same factors.

Figure 2 shows the total TFA contained in each lot of the studied brands. The values obtained for brand A in lots 1,2 , and 6 were between 3.19 and $3.76 \%$ of the total fatty acids, which are the highest TFA levels obtained in this study. Similar TFA levels were observed by Tang, ${ }^{17}$ who obtained values ranging between 1.6 and $3.8 \%$ for soybean oil brands available in Malaysia. A relevant decrease in the TFA levels was observed in brands B, C, and E from lots 3 and 4 on. These lots were produced between 3 and 6 months after the announcement made by the Brazilian Health Ministry that TFA concentrations should be indicated on food product labels. ${ }^{18}$ This shows the importance of governmental actions on the improvement of product quality. Fluctuations in the conditions of industrial processing such as temperature, vacuum, humidity and different sample origin can promote variations in the TPFA concentrations.

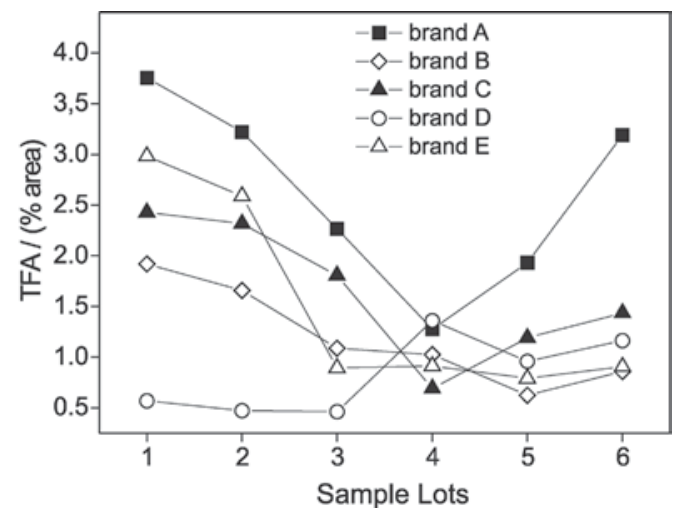

Figure 2. Total TFA contents of each lot of the studied brands.

Although the limits of TFA levels in refined vegetable oils have not been clearly determined, oils presenting levels under $1.0-1.5 \%$ are considered good. ${ }^{19}$ A TFA limit of $2.0 \%$ of the total fatty acids has been set for food products in Denmark. ${ }^{20}$ The Brazilian legislation establish that oils with lower than $0.2 \mathrm{~g}$ of TFA/portion can be labeled as free of TFA, but did not define the mass of a portion. The limit corresponds to $1 \%$ of the total calories that a person should consume in one day $(2000 \mathrm{kcal})$ considering that fat has $9 \mathrm{kcal} \mathrm{g}^{-1}$. From the oils analyzed in this study, only brand D exhibited TFA levels lower than $1.5 \%$ in all the studied lots. Brand B presented the second lowest levels, with values lower than $2.0 \%$.

\section{Conclusions}

Results indicate that probably of the thermal treatment applied to soybean oil during the deodorization step has been too intense in the last years leading to the high degree of isomerization of alpha-linolenic acid in lots 1 and 2 of most of the analyzed brands. The hypothesis is reinforced mainly when it is taken into account that the literature has showed that natural vegetable oils did not contain significant concentration of TPFA before the industrialization process. The isomerization contributes to a significant reduction of the daily intake of alpha-linolenic acid, since soybean oil is one of the main sources of this acid for the Brazilian population. Furthermore, it results in a larger TPFA intake and in an increase in the n-6/n-3 ratio of the diet. The law regulating the indication of TFA concentration on food product labels has brought positive results as it led to a reduction of the TPFA levels of most of the analyzed brands.

\section{Acknowledgments}

The authors are grateful to CAPES, CNPq, and Fundação Araucária for the financial support.

\section{References}

1. Turatti, J. M.; Gomes, R. A. R.; Athié, I.; Lipídeos: Aspectos Funcionais e Novas Tendências, Ed. UNICAMP: Campinas, 2002.

2. Enig, M. G.; Pallansch, L. A.; Sampugna, J.; Keeney, M.; J. Am. Oil Chem. Soc. 1983, 60, 1788. 
3. Wolff, R. L.; J. Am. Oil Chem. Soc. 1993, 70, 219.

4. Hénon, G.; Kemény, Z.; Recseg, K.; Zwobada, F.; Kovari, K.; J. Am. Oil Chem. Soc. 1996, 76, 73.

5. Sanibal, E. A. A.; Mancini-Filho, J.; Ciênc. Tecnol. Aliment. 2004, 24, 27.

6. Ascherio, A.; Katan, M. B.; Zock, P. L.; Stampfer, M. J.; Willett, W. C.; N. Engl. J. Med. 1999, 340, 1994.

7. Hunter, J. E.; Nutr. Res. 2005, 25, 499.

8. Vermunt, S. H.; Beaufrère, B.; Riemersma, R. A.; Sebédio, J. L.; Chardigny, J. M.; Mensink, R. P.; Br. J. Nutr. 2001, 85, 387.

9. Hartman, L.; Lago, R. C.; Lab. Pract. 1973, 22, 475.

10. Grangirard, A.; Prevost, F. J.; Sebedio, J. L.; J. Am. Oil Chem. Soc. 1987, 64, 1434.

11. Wolff, R. L.; J. Am. Oil Chem. Soc. 1992, 69, 106.

12. Ackman, R. G.; Progr. Chem. Fats Lipids 1972, 12, 165.

13. StatSoft, Statistica 5.1 software; Tucksa, USA, 1996.

14. Karabulut, I.; Kayahan, M.; Yaprak, S.; Food Chem. 2003, 81, 453.
15. Kris-Etherton, P. M.; Taylor, D. S.; Yu-Poth, S.; Huth, P.; Moriarty, K.; Fishell, V.; Hargrove, R. L. R. L.; Zhao, G.; Etherton, T. D.; Am. J. Clin. Nutr. 2000, 71, 179S.

16. Tasan, M.; Dermici, M.; J. Am. Oil Chem. Soc. 2003, 80, 825.

17. Tang, T. S.; J. Oil Palm Res. 2002, 14, 1.

18. ANVISA-Agência Nacional de Vigilância Sanitária; ResoluçãoRDC no 360, de 23 de dezembro de 2003 (Administrative Rules RDC No. 360, December 23, 2003). http://e-legis.anvisa.gov. br/leisref/public

19. Dionisi, F.; Golay, P. A.; Fay, L. B.; Anal. Chim. Acta 2002, 465, 395.

20. Danish Ministry of Food, Agriculture and Fisheries $\mathrm{n}^{\circ}$ 160; Executive Order on the Content of Trans Fatty Acids in Oils and Fats. Danish Veterinary and Food Administration, 2003.

Received: April 2, 2007 Published on the web: January 28, 2008 